Research Article

\title{
The Prevalence of Occult Omental Metastases in Patients with Epithelial Ovarian Cancer
}

\section{Prevalensi Occult Metastasis di Omentum pada Pasien Penderita Kanker Ovarium Epithelial}

\author{
Hariyono Winarto, Ken Indra \\ Department of Obstetrics and Gynecology \\ Faculty of Medicine Universitas Indonesia/ \\ Dr. Cipto Mangunkusumo National Hospital \\ Jakarta
}

\begin{abstract}
Objective: Studies regarding omentectomy on epithelial ovarian cancer are scarce with conflicting results; this study is aimed to investigate the prevalence of occult metastases in patients with epithelial ovarian cancer of the omentum.

Methods: A cross-sectional study design was used by evaluating the medical records of surgically staged ovarian cancer patients in $\mathrm{Dr}$. Cipto Mangunkusumo Hospital, Jakarta, Indonesia during the period of January 2009 to December 2015.

Results: A total of 51 subjects were involved in this study. One $(2 \%)$ of 51 subjects was found to have occult metastases in the omentum. The prevalence of metastases of early stage epithelial ovarian cancer in $2009-2015$ is $33.3 \%$ (17 out of 51 subjects), whereas the omental involvement is found only in $2 \%$ subjects (1 out of 51 ).

Conclusion: The prevalence of occult metastases of early stage epithelial ovarian cancer in Dr. Cipto Mangunkusumo Hospital, Jakarta, Indonesia, from 2009-2015 in 2\% (1/51 subjects).

[Indones J Obstet Gynecol 2018; 6-2: 119-122]

Keywords: cancer, epithelial, metastases, omentum, ovarian cancer, ovary, prevalence
\end{abstract}

\begin{abstract}
Abstrak
Tujuan: Mengenai omentektomi dalam pembedahan kanker ovarium epitelial masih sangat terbatas dengan hasil yang bervariasi sehingga dilakukan penelitian ini di Rumah Sakit Dr. Cipto Mangunkusumo (RSCM).
\end{abstract}

Metode: Penelitian ini menggunakan desain potong silang dengan mengambil rekam medis pasien kanker ovarium yang dilakukan pembedahan di RSCM pada bulan Januari 2009 - Desember 2015.

Hasil: Sebanyak 1 subjek dari 51 subjek penelitian (2\%) ditemukan occult metastasis pada omentum. Kejadian metastasis pada kanker ovarium epithelial stadium dini pada tahun 2009 - 2015 adalah sebesar 33,3\% (17 dari 51 subjek), di mana keterlibatan omentum ditemukan pada $2 \%$ subjek (1 dari 51 ).

Kesimpulan: Kejadian occult metastasis kanker ovarium epithelial stadium klinis dini yang dilakukan pembedahan di RSCM tahun 2009 - 2015 adalah sebesar 2\% (1 dari 51 subjek).

[Maj Obstet Ginekol Indones 2018; 6-2: 119-122]

Kata kunci: epithelial, kanker, metastasis, omentum, ovarium, prevalensi

\section{INTRODUCTION}

Ovarian cancer accounts for approximately 3\% of all cancer occurring in women. The prevalence is relatively stable since $1992 .{ }^{1}$ The main spread of ovarian cancer is through the trans-coelomicpath therefore it often involves abdominal viscera, peritoneum and omentum., ${ }^{2,3}$ The omentum of early stage ovarian cancer patient often times don't appear to have macroscopic lesions, yet FIGO stated that omentectomy need to be performed for adequate surgery for all stages. ${ }^{4}$ The role of omentectomy as a therapeutical modality for early stage ovarian cancer cannot be concluded. ${ }^{4}$ The function of omentum is mainly as a defense against infection, omentum can also be used for various surgical procedure, be it in general surgery or gynecologic surgeries. ${ }^{5-8}$ Complication of omentectomy may increase the risk of developing organ injury such as intestines, spleen and bleeding. ${ }^{9,10}$ Vinokurov found that the prevalence of omental metastases in all stages of ovarian cancer is $73.9 \%{ }^{11}$ Terauchi stated that the prevalence of omental metastases was $47 \%$ ( $9 / 19$ subjects), indicating that omentum is one of the major spread locations of ovarian cancer, and omentectomy should be performed if possible. ${ }^{12}$ Those studies didn't specifically explain the omentum condition or the stage of ovarian 
cancer when the surgery performed. Other sources stated that the prevalence of occult metastases of epithelial ovarian cancer in omentum varied from 0 to $13 \% \%^{4,13-15}$ Studies regarding omentectomy in epithelial ovarian cancer surgery are scant, and the results were contradictory. We aim to investigate the prevalence of epithelial ovarian cancer in Indonesia.

\section{METHODS}

This study used cross sectional study design. Data were collected from medical records of patients diagnosed with ovarian cancer who went to Dr. Cipto Mangunkusumo Hospital during the period of January 2009 to December 2015. Data were taken from the Cancer Registry of Oncology Gynecology of Obstetric and Gynecological Department of Dr. Cipto Mangunkusumo Hospital, Faculty Medicine - Universitas Indonesia. Inclusion criteria were women who were diagnosed with ovarian cancer and had undergone surgical staging. Those who underwent surgery without omentectomy, those who had clinically advanced ovarian cancer, and patients with pathological results non-epithelial or incomplete data.

\section{RESULTS}

\section{Subject's characteristics}

A total of 401 subjects were recruited in this study. Of these, 120 were of epithelial ovarian cancer with primary surgery, and 105 were those who underwent omentectomy. Of these, 51 cases were found with early stage.

Table 1. Characteristics of Subjects

\begin{tabular}{lcc}
\hline \hline Characteristics & n & \% \\
\hline Clinical Stage & & \\
Stage 1 & 41 & 80.4 \\
Stage 2 & 10 & 19.6 \\
Histopathology Stage & & \\
Stage 1 & 35 & 68.6 \\
Stage 2 & 7 & 13.7 \\
Stage 3 & 8 & 15.7 \\
Stage 4 & 1 & 2 \\
Subtype & & \\
Clearcell & 19 & 37.2 \\
Endometrioid & 10 & 19.6 \\
Mucinous & 9 & 17.7 \\
Serous & 13 & 25.5
\end{tabular}

\begin{tabular}{lcc} 
Omentum Pathology & & \\
$\quad$ Negative & 50 & 98 \\
$\quad$ Positive & 1 & 2 \\
Macroscopic appearance of omentum & & \\
$\quad$ Normal & 51 & 100 \\
Grade & & \\
N/A & 8 & 15.7 \\
Low grade & 14 & 27.4 \\
Moderate & 13 & 25.5 \\
$\quad$ High grade & 16 & 31.4 \\
\hline \hline
\end{tabular}

Table 2. Prevalence of Metastases of Epithelial Ovarian Cancer in RSCM from 2009-2015

\begin{tabular}{lccc}
\hline \hline & & $\mathbf{n}$ & $\mathbf{\%}$ \\
\hline Metastases & No $(-)$ & 34 & 66.7 \\
& Yes $(+)$ & 17 & 33.3 \\
\hline Total & & 51 & 100.0 \\
\hline \hline
\end{tabular}

Out of 51 subjects of early stage epithelial ovarian cancer, we found 17 from 51 patients with positive metastases $(33.3 \%)$ on uterus, omentum, appendix, lymph nodes, or cytology. Therefore prevalence of early stage epithelial ovarian cancer in RSCM from $2009-2015$ is $33.3 \%$ (17/51). From 51 clinically early stage epithelial ovarian cancer in RSCM from 2009-2015, we found 16 cases that experienced upstaging from histopathological examination and 35 cases remained as early stage (31.3\% and $68.7 \%)$

Table 3. Prevalence of Omental Occult Metastases of Epithelial Ovarian Cancer

\begin{tabular}{cccc}
\hline \hline Macroscopic & Histopathology & $\mathbf{n}$ & $\mathbf{\%}$ \\
\hline No macroscopic & Negative $(-)$ & 50 & 98 \\
anomaly & Positive $(+)$ & 1 & 2 \\
\hline Total & & 51 & 100.0 \\
\hline \hline
\end{tabular}

Prevalence of occult metastases of early stage epithelial ovarian cancer in omentum in RSCM from $2009-2015$ is $2 \%(1 / 51)$, the subject is clinically stage 2 .

\section{DISCUSSION}

\section{Prevalence of early stage epithelial ovarian cancer metastases in RSCM from 2009 - 2015}

Out of 51 early stage epithelial ovarian cancer, we found 17 from 51 patients with positive metastases 
(33.3\%) in uterus, omentum, appendix, lymph node or cytology. The prevalence of early stage epithelial ovarian cancer in RSCM from 2009-2015 is $33.3 \%(17 / 51)$, literature recommend to perform routine surgical staging and we found $30 \%$ of upstaging from early stage ovarian cancer (stage 1 and stage 2), with omental involvement around $0-11 \%$ cases. ${ }^{5,16,17}$

\section{Prevalence of upstaging of epithelial ova- rian cancer clinically early stage in RSCM from 2009-2015}

From 51 patients with clinically early stage ovarian cancer in RSCM from 2009-2015, we found 16 cases upstaged from the pathological examination and 35 cases remain early stage $31.3 \%$ and $68.7 \%$.) This result is similar to Garcia Soto et al who studied epithelial ovarian cancer clinically early stage who underwent surgical staging with 86 subjects, where 25 out of 86 subjects (29\%) were upstaged. ${ }^{18}$

\section{Prevalence of occult metastases of epithe- lial ovarian cancer clinically early stage to the omentum}

In this study we found occult metastases prevalence of epithelial ovarian cancer around 2\% (1/51). From literature we found that the range of prevalence of occult metastases in the omentum is around $0-13 \%$. This result is similar to other studies. ${ }^{16,18-21}$

\section{Distribution of epithelial ovarian cancer metastases in omentum based on its sub- type}

We found that the subject who had metastases in the omentum were patients with serous subtype, we didn't found metastases on other subtypes. Using Fisher's exact test we found no correlation between these two variables $(\mathrm{p}=0.6)$. This result is similar to what Garcia Soto et al found in 2012 that the histology of ovarian cancer is an independent variable to metastases. ${ }^{16,18}$

\section{Distribution of epithelial ovarian cancer based on its grade}

We found that the subject with omental metastases were patients with poorly differentiated tumors.
No metastases to the omentum from patients with good or moderately differentiated tumors. Using Fisher's exact test we found no correlation between the grade of tumor to the metastases. This result is contradictory with Ayhan's results that grade $(p<0.03)$ is correlated significantly with the stage of the disease. ${ }^{19}$

\section{CONCLUSION}

The prevalence of occult omental metastases in early stage epithelial ovarian cancer in Dr. Cipto Mangunkusumo Hospital during the year of 2009 to 2015 was $2 \%$.

\section{REFERENCES}

1. Tarver. American Cancer Society. Cancer Facts \& Figures 2015; p.19. Atlanta: American Cancer Society; 2015.

2. Medscape. Metastatic ovarian cancer. [Internet]. [cited 2015 Oct 8];Available from: http://www.medscape.org/viewarticle/456046.

3. Cancer O. Metastatic Patterns in Histologic Variants. 1989: 1508-13.

4. DiSaia PJ, Creasman WT. Clinical Gynecologic Oncology $7^{\text {th }}$ ed. 2007: 300-1.

5. Benedet JL, Bender H, Jones III H, Ngan HYS, Pecorelli S. Staging classifications and clinical practice guidelines of gynaecologic cancers. Int J Gynecol Obstet [Internet]. 2000; 70: 207-312. Available from: http://www.igcs.org/files/ TreatmentResources/FIGO_IGCS_staging.pdf

6. Alagumuthu M, Das B, Pattanayak S, Rasananda M. The omentum - A unique organ of exceptional versatility. Indi J Surg 2006; 68: 136-41.

7. Platell C, Cooper D, Papadimitriou JM, Hall JC. The omentum. 2000; 6(2): 169-76.

8. Dickinson G. The omentum and its functions. Ann Sur 1906; 44(5): 652-65.

9. NICE. Ovarian cancer?: recognition and initial management. (CG122) 2011. p.09-16. accessed from http://nice.org.uk/ guidance/cg122.

10. Hauspy J, Kupets R, Covens AL. Miscellaneous, Including Omentectomy, Appendectomy, Lysis Adhesions, and Splenectomy. Laparoscopic Sur Gynecol Oncol. 2008: 143-55.

11. Vinokurov V, Kolosov A. Ovarian cancer metastases to the greater omentum. Vopr Oncol 1980; 30-4.

12. Terauchi F, Tanabe K, Tenmyo M, Terauchi H, Ogura H. Clinical Study on total omentumectomy for ovarian cancer. Nihon Sanka Fujinka Gakkai Zasshi 1995; 14-8.

13. Cancer O, By E, Rubin SC, et al. Ovarian Cancer $2^{\text {nd }}$ ed. 2001: p.107.

14. Sundar S, Reynolds K. Benign and Malignant Ovarian Masses. In: Luesley DM, Baker PN, editors. Obstetrics and Gynaecology: An Evidence-Based Text for MRCOG 2010: 904.

15. Berek JS. Epithelial Ovarian Cancer. Berek and Novak's Gynecology 14th ed. 2007: 1458-85. 
16. Ben A, Mcnally L, Kapp DS, Teng NNH. The omentum and omentectomy in epithelial ovarian cancer?: A reappraisal Part II - The role of omentectomy in the staging and treatment of apparent early stage epithelial ovarian cancer. Gynecol Oncol [Internet] 2013; 131(3): 784-90. Available from: http://dx.doi.org/10.1016/j.ygyno.2013.09.013

17. FIGO. FIGO Ovarian cancer staging. 2014: 1-2.

18. Garcia-soto AE, Boren T, Wingo SN, Heffernen T, Miller DS, Club SJ. Is comprehensive surgical staging needed for thorough evaluation of early-stage ovarian carcinoma? YMOB [Internet] 2012; 206(3): 242.e1-242.e5. Available from: http://dx.doi.org/10.1016/j.ajog.2011.08.022
19. Ayhan A, Gultekin M, Celik NY, Dursun P, Taskiran C. Occult metastases in early ovarian cancers: risk factors and AJOG 2007; 81: 1-6.

20. Usubutun A, Ozseker HS, Himmetoglu C, Balci S, Ayhan A. Omentectomy Gynecol Cancer. 2007; 13: 1578-81.

21. Steinberg J, Demopoulos R, Bigelow B. Evaluation of omentum in ovarian cancer. 1986: 327-30. 